\title{
In vitro and in vivo antibacterial effect of NZ2114 against Streptococcus suis type 2 infection in mice peritonitis models
}

\author{
Jian Jiao ${ }^{1,2,3 \dagger}$, Ruoyu Mao ${ }^{1,2 \dagger}$, Da Teng ${ }^{1,2}$, Xiumin Wang ${ }^{1,2}$, Ya Hao ${ }^{1,2}$, Na Yang $^{1,2}$, Xiao Wang ${ }^{1,2}$, Xingjun Feng ${ }^{3}$ \\ and Jianhua Wang ${ }^{1,2^{*}}$
}

\begin{abstract}
NZ2114 is a promising candidate for therapeutic application owing to potent activity to gram-positive bacterium such as Streptococcus pneumoniae and Staphylococcus aureus. This work is the first report to describe the in vitro and in vivo antibacterial characteristics of NZ2114 against Streptococcus suis. It exhibited strong antimicrobial activity against S. suis type 2 strains CVCC 606, CVCC 3309, and CVCC 3928 at a low minimal inhibitory concentration (MIC) of 0.03-0.06 $\mu \mathrm{M}$. The NZ2114 killed over 99.9\% of tested S. suis CVCC 606 in Mueller-Hinton medium within $4 \mathrm{~h}$ when treated with $4 \times$ MIC. It caused only less than $0.25 \%$ hemolytic activity in the concentration of $256 \mu \mathrm{g} / \mathrm{ml}$. Additionally, NZ2114 exhibited potent in vivo activity to S. suis. All mice were survival when the dosage was low to $0.2 \mathrm{mg} / \mathrm{kg}$. Over $99 \%$ of S. suis cells were killed within $4 \mathrm{~h}$ in blood, lung, liver and spleen with dosage of 10, 20, and $40 \mathrm{mg} / \mathrm{kg}$ in mice peritonitis models and no pathogen were detected after $24 \mathrm{~h}$ of treatment. Further, no pathological phenomenon in lung and low level of inflammatory cytokines in blood were detected. These results indicate that NZ2114 has the potential to be a new antimicrobial agent candidate for the clinical treatment of infection caused by S. suis type 2 .
\end{abstract}

Keywords: Antimicrobial peptides, NZ2114, Streptococcus suis, Anti-S. suis in vivo

\section{Introduction}

Streptococcus suis is an important pathogen associated with wide range of diseases in swine and human, including septicemia, pneumonia, endocarditis, meningitis, and arthritis (Lun et al. 2007). It was found that S. suis was the fourth most significant pathogen in the breeder and weaner site. S. suis can be transmitted to human beings by direct contact. The repeated intensive outbreaks of human S. suis infection have raised great public concern worldwide regarding $S$. suis as an emerging zoonotic pathogen. It is the most common cause of adult infection in Vietnam (Mai et al. 2008) and the second most common in Thailand (Suankratay et al. 2004). In Europe, the largest number of zoonotic infections due to $S$. suis, have

\footnotetext{
*Correspondence: wangjianhua@caas.cn; 2681298635@qq.com

${ }^{\dagger}$ Jian Jiao and Ruoyu Mao contributed equally to this work

${ }^{2}$ Gene Engineering Laboratory, Feed Research Institute, Chinese Academy of Agricultural Sciences, 12 Zhongguancun Nandajie Street, Haidian District, Beijing 100081, People's Republic of China

Full list of author information is available at the end of the article
}

been recorded in the Netherlands [Figure 1 in (Wertheim et al. 2009)]. In July, 2005, the largest outbreak of human S. suis infection occurred in Sichuan province, China, where 204 people were infected and 38 of them died (Normile 2005). There are 35 serotypes described and the composition of the capsule defines the serotype (types $1-34$ and $1 / 2$ ). Serotype 2 is commonly associated with diseases in pigs and human beings, and is the most frequently reported serotype worldwide (Costa et al. 2005). It has always been considered the most virulent serotype (Higgins and Gottschalk 2000).

S. suis type 2 is resistant to various environmental conditions. It can survive for $10 \mathrm{~min}$ at $60{ }^{\circ} \mathrm{C}, 2 \mathrm{~h}$ at $50{ }^{\circ} \mathrm{C}$, and 6 weeks in carcasses at $10{ }^{\circ} \mathrm{C}$ (Clifton-Hadley and Enright 1984). The penicillin G, accompanied by one or more other antibiotics including ceftriaxone, gentamicin, chloramphenicol, and ampicillin is the normal strategy for S. suis infection treatment (Halaby et al. 2000). However, with wide and over use of antibiotics, S. suis is resistant to many conventional drugs. More than $87 \%$ of 
S. suis isolates are resistant to oxytetracycline, erythromycin, tylosin tartrate, and clindamycin in Spain (Vela et al. 2005). In addition, high levels of tetracycline resistance (upto 90\%) have also been reported from diseased and clinically healthy persons (Hoa et al. 2011; Strangmann et al. 2002). Integrative conjugative elements (ICE) seem to play a key role in the transmission of resistance determinants, as demonstrated by genomic studies. Although S. suis is uniformly sensitive to penicillin or ampicillin, and low levels of resistance are reported (Varela et al. 2013), there will be rare candidates when resistance arise. In the other side, vaccines are the common strategy for the prevention of S. suis infection. Although various of vaccines are developed, the commonly used vaccines in pig industry, however, remain the inactivated autogenous vaccine generated from virulent strains isolated from sick pigs (Haesebrouck et al. 2004). One of the disadvantages of autogenous vaccines is the absence of safety and efficacy data. At present, there is no S. suis vaccine for human beings (Lun et al. 2007). To prevent and treat infections caused by $S$. suis, novel and effective antimicrobial agents are needed.

Plectasin is a fungal defensin from Pseudoplectania nigrella and is active against Gram-positive bacteria such as Staphylococcus aureus ( $\mathrm{MIC}_{50} 16 \mu \mathrm{g} / \mathrm{ml}$ for methicillinsensitive strains and $32 \mu \mathrm{g} / \mathrm{ml}$ for resistant strains) and $S$. pneumoniae $\left(\mathrm{MIC}_{50} 1 \mu \mathrm{l} / \mathrm{ml}\right.$ for both penicillin-sensitive and resistant strains) by coalescing with the pyrophosphate moiety of lipid II, the essential precursor of the cell wall (Mygind et al. 2005; Schneider et al. 2010). Peptide NZ2114 is a novel variant of plectasin (D9N, M13L, Q14R) that is significantly more potent than parental peptide $\left(\mathrm{MIC}_{50} 2 \mu \mathrm{g} / \mathrm{ml}\right.$ for $S$. aureus and $0.25 \mu \mathrm{g} / \mathrm{ml}$ for S. pneumoniae) (Andes et al. 2009; Ostergaard et al. 2009; Zhang et al. 2014). It also owned long postantibiotic effect (PAE) (Andes et al. 2009) and was synergistic in combination with teicoplanin, moenomycin, and dalbavancin (Breidenstein et al. 2015). It had potent activities against $S$. aureus in rabbit meningitis, murine peritonitis, and thigh infection models (Andes et al. 2009; Ostergaard et al. 2009; Xiong et al. 2011). Additionally, NZ2114 showed low or no cell toxicities, long-lasting serum stability and in vivo half-life (Brinch et al. 2010). However, there are no studies focused on its activity against $S$. suis, the important zoonotic pathogens. In this work, the in vitro effect of NZ2114 against S. suis was investigated. Furthermore, the in vivo pharmacodynamics characteristics were evaluated for future clinical development.

\section{Materials and methods Materials}

The antimicrobial peptide NZ2114 was prepared according to a previously described protocol (Zhang et al.
2014), and its purity was $94.8 \%$. The purified, lyophilized NZ2114 powder was dissolved in sterilized ultrapure water and stored at $-20{ }^{\circ} \mathrm{C}$ before subsequent antibacterial assessments.

\section{Minimal inhibitory concentration (MIC) assay}

The MICs of NZ2114 were determined by the microtiter broth dilution method in 96 micro-well plate (Tian et al. 2009). The pathogens were grown to 0.4 of $\mathrm{OD}_{600 \mathrm{~nm}}$ at $37{ }^{\circ} \mathrm{C}$ in $\mathrm{MHB}$ medium and diluted to approximate $1 \times 10^{5} \mathrm{CFU} / \mathrm{ml}$ with fresh MHB medium. The purified NZ2114 was twofold serial dilutions with gradient concentration of $1280,640,320,160,80,40,20,10,5,2.5$, 1.25 , and $0.625 \mu \mathrm{g} / \mathrm{ml}$. A $90-\mu \mathrm{l}$ cell suspension and $10 \mu \mathrm{l}$ of serial concentration gradient solutions of NZ2114 were added to every well. All assays were performed in triplicate. The ampicillin was also tested with the same concentration gradient as controls. Plates were incubated at $37^{\circ} \mathrm{C}$ for $18-24 \mathrm{~h}$. The MIC was defined as the lowest concentration of ones at which there was no visible growth.

\section{Bactericidal kinetics assay}

The $S$. suis strain CVCC 606 was grown overnight in $\mathrm{MH}$ medium at $37{ }^{\circ} \mathrm{C}$ with shaking at $250 \mathrm{rpm}$. Fresh $\mathrm{MH}$ medium was inoculated with $1 \%(\mathrm{v} / \mathrm{v})$ overnight culture and grown to mid-log phase. The $90 \mu \mathrm{l}$ of exponential-phase S. suis strain CVCC 606 (approximately $10^{4-5} \mathrm{CFU} / \mathrm{ml}$ ) cells were incubated with $10 \mu \mathrm{l}$ of NZ2114 (final concentrations were $1 \times, 2 \times$, and $4 \times \mathrm{MIC}$ ); the $2 \times$ MIC ampicillin was used as control. The mixed samples were added to the wells of 96-well cell culture plates (each concentration sample was performed in triplicate) and incubated at $37{ }^{\circ} \mathrm{C}$. The $100 \mu \mathrm{l}$ samples from each well were collected after $0,0.5,1,2,3,4,6,8$, and $10 \mathrm{~h}$ of incubation and were serially diluted and plated on $\mathrm{MH}$ agar. Viable colonies were counted after $16-18 \mathrm{~h}$ at $37^{\circ} \mathrm{C}$.

\section{Hemolytic assay}

The hemolytic activity of NZ2114 was evaluated by determining the amount of released hemoglobin from a $4 \%$ suspension of fresh mice red blood cells (RBCs) (Cho and Lee 2011). Mice RBCs were collected and washed with physiological saline (PS) three times. The $100 \mu \mathrm{l}$ of mice RBCs diluted to $8 \%(\mathrm{v} / \mathrm{v})$ in PS was seeded into 96-well plates, and a $100 \mu \mathrm{l}$ peptide solution was then added to each well (at a final concentration ranging from 0 to $256 \mu \mathrm{g} / \mathrm{ml}$ ). The plates were incubated at $37^{\circ} \mathrm{C}$ for $1 \mathrm{~h}$ and centrifuged at $1500 \mathrm{rpm}$ for $10 \mathrm{~min}$. Absorbance of the supernatants at $540 \mathrm{~nm}$ was measured with an ELISA plate reader, and 0 and $100 \%$ hemolysis was determined in PS and $0.1 \%$ Triton X-100, respectively. The hemolysis percentages were calculated by the following 
equation: $\left[\left(\mathrm{Abs}_{540 \mathrm{~nm}}\right.\right.$ in NZ2114 solution $-\mathrm{Abs}_{540 \mathrm{~nm}}$ in PS) $/\left(\mathrm{Abs}_{540 \mathrm{~nm}}\right.$ in $0.1 \%$ Triton X-100 $-\mathrm{Abs}_{540 \mathrm{~nm}}$ in PS) $] \times 100 \%$.

\section{Animals}

The 6-week-old female Institute for Cancer Research (ICR) mice, SPF, weighing 20-25 g were used for all in vivo test. Mice were purchased from Wei Tonglihua Co., Ltd (Beijing). Animals were kept in standard Macrolon cages (5-8 per cage), fed a standard pellet diet ad libitum, and had free access to bottled drinking water. Animals were acclimatized for 2-3 days prior to the initiation of the study.

\section{Streptococcus suis infection model}

Streptococcus suis CVCC606 bacteria were grown to logarithmic phase $\left(\mathrm{OD}_{600 \mathrm{~nm}}, 0.5\right)$, harvested, washed in PBS, diluted in the same buffer to 8.5-9.5 lg CFU/ml, and kept on ice until injection. Every ten mice were divided into a group. A $100 \mu \mathrm{l}$ of certain concentration of bacterial suspension was inoculated intraperitoneally (i.p.). The PBS was used as control. After injection of bacteria, survival rate was monitored for 7 days.

\section{Effects of NZ2114 against S. suis in vivo}

To test the protective effect of NZ2114 against S. suis infections in vivo, every ten ICR female mice were divided into one group. Each group was inoculated i.p. with $1 \times 10^{8}$ CFU S. suis CVCC606 and various concentration of NZ2114 $(0.04,0.2,1,2.5,5,10,20$, and $40 \mathrm{mg} /$ $\mathrm{kg}$ ) were injected intravenously (i.v.) after 1 and $8 \mathrm{~h}$ postinfection. The PBS and $10 \mathrm{mg} / \mathrm{kg}$ ampicillin was used as control. After injection of bacteria and drugs, survival rate was monitored for 7 days. Additionally, the blood and lung were collected after $24 \mathrm{~h}$ post-treatment; bacterial loads in these tissues were calculated.

The bacterial loads in different tissues after treatment with NZ2114 at different time points were determined. ICR female mice inoculated with $1 \times 10^{8} \mathrm{CFU}$ S. suis CVCC606 and various concentration (10, 20, and $40 \mathrm{mg} /$ $\mathrm{kg}$ ) of NZ2114 was injected i.v. after 1 and $8 \mathrm{~h}$ postinfection. The mice were sacrificed by cervical dislocation; bacterial loads in blood, lung, spleen, and liver were detected in $0,2,4,8$, and $16 \mathrm{~h}$ post-treatment. Every six mice were divided into one group and as duplicate.

\section{Histological analysis of lung}

ICR female mice were inoculated with $1 \times 10^{8} \mathrm{CFU} S$. suis CVCC606 and various concentration of NZ2114 $(10,20$, and $40 \mathrm{mg} / \mathrm{kg})$ was injected after 1 and $8 \mathrm{~h}$ postinfection. The $10 \mathrm{mg} / \mathrm{kg}$ ampicillin was used as control. The mice were sacrificed after $24 \mathrm{~h}$ post-treatment and the lungs were removed and immediately dipped into
4\% paraformaldehyde solution in PBS for 1-3 days. The tissues were then embedded in paraffin, sectioned and $4 \mathrm{~mm}$ sections were placed on glass slides. Slides underwent deparaffinization and staining by hematoxylin and eosin.

\section{Cytokine assay}

ICR female mice were inoculated with $1 \times 10^{8}$ CFU $S$. suis CVCC606 and various concentration of NZ2114 $(10,20$, and $40 \mathrm{mg} / \mathrm{kg})$ was injected after 1 and $8 \mathrm{~h}$ postinfection. The $20 \mathrm{mg} / \mathrm{kg}$ ampicillin was used as control. Whole blood was collected by heart puncture after $24 \mathrm{~h}$ post-treatment. The blood was incubated at $37^{\circ} \mathrm{C}$ for $2 \mathrm{~h}$ and centrifuged at $3000 \mathrm{rpm}$ for $5 \mathrm{~min}$ at $4{ }^{\circ} \mathrm{C}$. Serum was collected from supernatant. The cytokines of TNF- $\alpha$, IL- 6 and IL-10 was detected by ELISA in Jiaxuan Biotech Co., Ltd (Beijing).

\section{Results}

Antimicrobial activity of NZ2114

The NZ2114 displayed potent antimicrobial activity against Gram-positive bacteria such as $S$. suis, $S$. aureus and S. pneumonia, especially for S. suis (MIC 0.03-0.06 $\mu \mathrm{M}$ ) (Table 1). The MBCs ranged from 0.06 to $0.12 \mu \mathrm{M}$. The activity of NZ2114 to $S$. aureus and $S$. pneumonia was lower than that to S. suis, with the MICs ranged from 0.03 to $0.9 \mu \mathrm{M}$ to $S$. aureus ATCC25923, 6538 and 43300 and $1.8-3.6 \mu \mathrm{M}$ to S. pneumonia CMCC31968 and 2350, respectively (Table 1). In addition, the activity of NZ2114 against $S$. suis was stronger compared to ampicillin (MIC 0.17-0.34 $\mu \mathrm{M}$ ) (Table 1).

\section{Time-killing curves of NZ2114}

Time-killing curves were generated to demonstrate the bactericidal ability of NZ2114 against S. suis CVCC606. As shown in Fig. 1a, in the absence of NZ2114, the bacterial counts $(\mathrm{lg} \mathrm{CFU} / \mathrm{ml}$ ) reached to 8.92 at $10 \mathrm{~h}$. It exerted a dose-related pattern of inhibition for S. suis CVCC606. A decrease in S. suis CVCC606 of 1.28 and $1.83 \mathrm{lg}$ CFU/ $\mathrm{ml}(>90 \%$ reduction) was observed within $3 \mathrm{~h}$ at one and two times of MIC, respectively. Those decreases were nearly equal to that obtained by ampicillin treatment (1.49 lg CFU/ml decrease) at two times of MIC (Fig. 1a), but NZ2114 failed to inhibit bacterial regrowth after 3 and $4 \mathrm{~h}$ of inoculate for $1 \times$ and $2 \times$ MIC, respectively. However, a huge and stable decrease was found within $10 \mathrm{~h}$ at $4 \times \mathrm{MIC}$ (lg CFU/ml from 5.13 to 2.64 , bactericidal efficiency $>99 \%$ ).

\section{Hemolytic assay}

The cytotoxicity of NZ2114 was tested by measuring its ability to lyse mice RBCs. There was no obvious hemolysis of RBCs within $64 \mu \mathrm{g} / \mathrm{ml}$ and the hemolytic activities 
Table 1 MIC and MBC assays of NZ2114 and ampicillin to S. suis, S. aureus, S. pneumonia, and E. coil

\begin{tabular}{|c|c|c|c|c|c|}
\hline \multirow[t]{2}{*}{ Strains } & \multirow[t]{2}{*}{ Source } & \multicolumn{2}{|l|}{$\mathrm{MIC}(\mu \mathrm{M})$} & \multicolumn{2}{|c|}{$\mathrm{MBC}(\mu \mathrm{M})$} \\
\hline & & NZ2114 & Ampicillin & NZ2114 & Ampicillin \\
\hline S. suis CVCC606 & $\mathrm{CVCC}^{\mathrm{a}}$ & 0.03 & 0.17 & 0.03 & 0.34 \\
\hline S. suis CVCC3309 & CVCC & 0.03 & 0.34 & 0.06 & 0.34 \\
\hline S. suis CVCC3928 & CVCC & 0.06 & 0.34 & 0.06 & 1.02 \\
\hline S. aureus ATCC25923 & CVCC & 0.03 & 1.35 & 0.06 & 1.35 \\
\hline S. aureus ATCC6538 & $\mathrm{CGMCC}^{\mathrm{b}}$ & 0.11 & 1.35 & 0.11 & 2.69 \\
\hline S. aureus ATCC43300 & CGMCC & 0.9 & 10.78 & 0.9 & 21.56 \\
\hline Streptococcus pneumoniae CGMCC1.8722 & CGMCC & 0.45 & 1.35 & 0.9 & 2.69 \\
\hline S. pneumoniae CVCC2350 & CVCC & 0.9 & 2.69 & 1.8 & 5.38 \\
\hline S.pneumoniae CVCC31968 & CVCC & 0.9 & 2.69 & 0.9 & 2.69 \\
\hline E.coli CVCC195 & CVCC & $\geq 29.09$ & 0.31 & $\geq 29.09$ & 0.31 \\
\hline E.coli CVCC1515 & CVCC & $\geq 29.09$ & NT & $\geq 29.09$ & NT \\
\hline
\end{tabular}

NT no tested

a China Institute of Veterinary Drug Control

b China General Microbiological Culture Collection Center
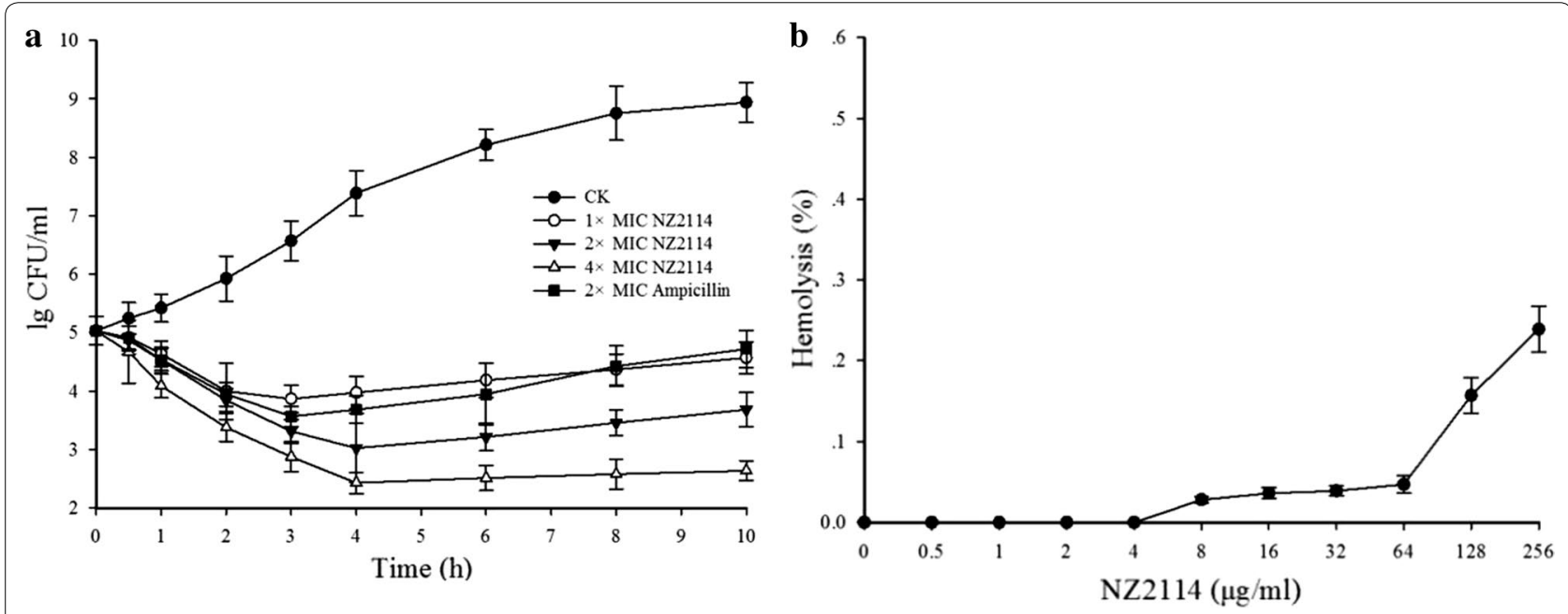

Fig. 1 Time-killing curves and hemolytic assay of NZ2114. a Time-killing curves of NZ2114 against S. suis CVCC606. S. suis CVCC606 were incubated in the presence of medium alone (CK), in the presence of NZ2114 at 1×,2 , and $4 \times$ MIC, or in the presence of ampicillin at $2 \times$ MIC, three duplicate observations were made; bars represent the standard error of the mean. $\mathbf{b}$ Hemolytic assay of NZ2114. The 4\% erythrocytes were incubated with different concentration of NZ2114, the $0.9 \% \mathrm{NaCl}$ and $0.1 \%$ Triton X-100 were used as negative and positive controls. Three duplicate observations were made; bars represent the standard error of the mean

at concentrations of 128 and $256 \mu \mathrm{g} / \mathrm{ml}$ were 0.153 , $0.241 \%$, respectively (Fig. 1b). It is critical that NZ2114 displays little or no hemolytic activity for its application in internal medicine.

\section{Absolute lethal dose assay}

As shown in Fig. 2, all mice were alive when i.p. injected with PBS after 7 days. The survival rate of mice injected with 8.5 and $8.75 \mathrm{lg} \mathrm{CFU} / \mathrm{ml} \mathrm{S}$. suis CVCC606 were 80 and $60 \%$, respectively. All mice were died at 7 days after injected with 9, 9.25, and 9.5 lg CFU/ml S. suis CVCC606.
However, the mice injected with $9.5 \mathrm{lg} \mathrm{CFU} / \mathrm{ml}$ bacteria were died immediately within only 1 day, and the mice injected with 9 and $9.25 \mathrm{lg} \mathrm{CFU} / \mathrm{ml}$ bacteria were died at 3 days postinjection. To evaluate the therapeutic effects in a continuous way, the inoculum concentration of $9 \mathrm{lg} \mathrm{CFU} / \mathrm{ml}$ was chosen to further research.

\section{Dosage effect of NZ2114}

It was shown that NZ2114 improved survival for all treatment groups (Fig. 3a). All mice injected with $0.2-$ $40 \mathrm{mg} / \mathrm{kg} \mathrm{NZ2114}$ were alive except that of $0.04 \mathrm{mg} / \mathrm{kg}$ 


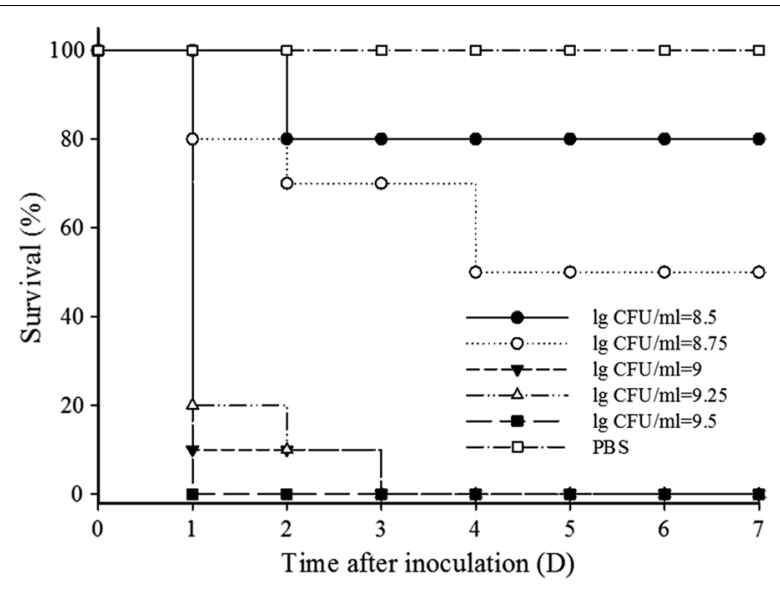

Fig. 2 Absolute lethal dose assays. Every ten mice were divided into a group. Each group was injected with a certain concentration of $S$. suis CVCC606 (100 $\mu \mathrm{l}$ of 8.5-9.5 lg CFU/ml). The PBS was used as control. After injection of bacteria, survival rate was monitored for 7 days

(Fig. 3a). No obvious colony was observed in the blood of mice injected with $5-40 \mathrm{mg} / \mathrm{kg}$ NZ2114. However, the $\lg$ CFU/ml of S. suis CVCC606 increased significantly from 0.74 to 6.50 with the NZ2114 concentration of 2.5, $1,0.2$ and $0.04 \mathrm{mg} / \mathrm{kg}$, respectively (Fig. $3 \mathrm{~b}$ ). In addition, NZ2114 with the concentration of $10,20,40 \mathrm{mg} /$ $\mathrm{kg}$ could effectively kill the pathogens and no colony was observed in lung after $24 \mathrm{~h}$ of injection. The $\mathrm{lg}$ CFU/ml of S. suis CVCC606 was 2.01 and 2.04 with the dosage of 5 and $2.5 \mathrm{mg} / \mathrm{kg}$ and it increased from 3.23 to 5.64 with the reduction of injection dose $(1,0.2$, and $0.04 \mathrm{mg} / \mathrm{kg})$ (Fig. 3c).

\section{Effects of NZ2114 against S. suis on various organs}

The bacterial loads in different organs were monitored at $2,4,8,16$, and $24 \mathrm{~h}$ postinfection after treatment with NZ2114 and control ampicillin. S. suis was distributed at high concentrations in different organs and blood at $4 \mathrm{~h}$ (8.97-11.87 $\mathrm{lg} \mathrm{CFU} / \mathrm{ml})$ and $8 \mathrm{~h}$ (9.92-12.06 lg CFU/ml) postinfection. Meanwhile, the bacterial loads in blood showed sharp decrease and hardly detected at $16 \mathrm{~h}$ posttreatment with 10, 20, and $40 \mathrm{mg} / \mathrm{kg} \mathrm{NZ2114}$. The ampicillins with $10 \mathrm{mg} / \mathrm{kg}$ led to $5.313 \mathrm{lg} \mathrm{CFU} / \mathrm{ml}$ reduction in 24. h postinfection (Fig. 4a).

The bacterial loads in lung, spleen, and liver showed obvious dose-dependent effect (Fig. 4b-d). There was significant reduction of the CFU counts in lung, with the most rapid decrease being observed in $4 \mathrm{~h}$ posttreatment, the bacterial loads were $2.560,2.903$, and $3.995 \mathrm{lg}$ CFU/0.1 g with 40, 20 and $10 \mathrm{mg} / \mathrm{kg}$ NZ2114, respectively. However, the bacterial loads remained stable until the retreatment in $8 \mathrm{~h}$ and no colony were detected in $24 \mathrm{~h}$ posttreatment (Fig. 4b). Similarly, there was significant reduction of the CFU counts in $4 \mathrm{~h}$ posttreatment, showing $\lg$ colony counts of 2.512, 4.345, 4.689 in spleen and 3.078, 4.313, 4.506 in liver for 40, 20, and $10 \mathrm{mg} / \mathrm{kg} \mathrm{NZ2114}$, respectively (Fig. 4c, d). Moreover, there was no colony in $24 \mathrm{~h}$ at all NZ2114 treatment groups.

\section{Effects of NZ2114 against S. suis infection in lung histopathology}

There was no histological sign of infection and inflammation in the lung tissue of uninfected group (Fig. 5a). In contrast, the histology of untreated mice showed severe inflammatory reactions such as infiltration of inflammatory cells, alveolar collapse, alveolar hemorrhage and bronchioli terminals epithelium damage (Fig. 5b). NZ2114 could reduce the lesions of lung tissues in a dose dependent manner (Fig. 5c-e). There was no obvious inflammation in the 20 and $40 \mathrm{mg} / \mathrm{kg}$ NZ2114 treatment group, which was recovered almost the same as uninfected group (Fig. 5d, e).

\section{Effects of NZ2114 in the cytokine levels}

To expose the anti-inflammatory effect of NZ2114 on mice, the levels of inflammatory cytokines TNF- $\alpha$, IL- 6 and IL-10 were analyzed after $24 \mathrm{~h}$ post-treatment. As shown in Fig. 6, there were low cytokine levels in the uninfected group $(13.798 \mathrm{pg} / \mathrm{ml}$ for TNF- $\alpha$ and $16.256 \mathrm{pg} / \mathrm{ml}$ for IL-6). The $S$. suis infection could significantly increase cytokine levels to 248.19 and $1458.60 \mathrm{pg} /$ $\mathrm{ml}$, respectively (Fig. 6a, b). Conversely, treatment with NZ2114 efficiently reduced the production of TNF- $\alpha$ and IL-6, reducing to the normal levels (15.679-19.671 pg/ml for TNF- $\alpha$ and $52.666-149.813 \mathrm{pg} / \mathrm{ml}$ for IL-6) (Fig. 6a, b). In contrast, no obvious changes of expression of IL-10 were exhibited in control and treatment groups (data not shown).

\section{Discussion}

Antimicrobial peptides (AMPs) have attracted much attention in recent years for their potent activity against a variety of pathogens, including drug-resistant bacteria. Currently, 2718 types of AMPs are registered in the antimicrobial peptide database (APD) (http://aps.unmc.edu/ $\mathrm{AP} /$ main.php). However, only a few of them advanced into clinical trials due to several bottlenecks, including poor antimicrobial activity, low stability, high toxicity and lack of efficient approaches to commercial-scale production (Eckert 2011; Yeung et al. 2011; Zasloff 2002). NZ2114 was a novel plectasin mutant identified through a high-throughput mutation, which had improved potency against $S$. aureus and S. pneumoniae (Andes et al. 2009; Ostergaard et al. 2009) and high expression yield (2.39 $\mathrm{g} / \mathrm{l}$ in the supernatant of Pichia pastoris) 


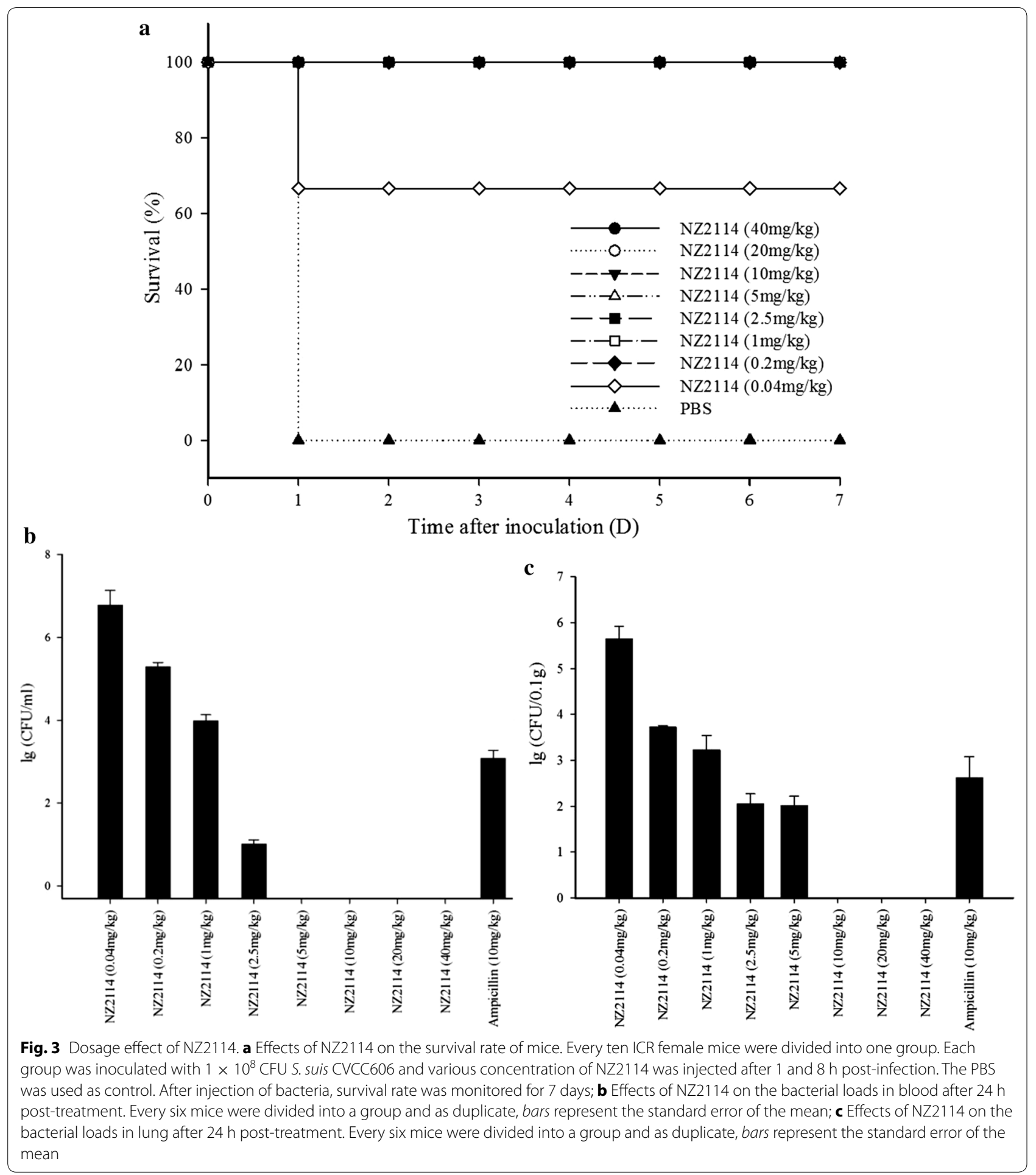

(Zhang et al. 2014). Our previous studies showed that, plectasin and its derived peptide MP1106 were very active against $\mathrm{G}^{+}$pathogens, such as $S$. suis, S. aureus and S. pneumonia, especially for S. suis (MIC 0.03-0.06 $\mu \mathrm{M}$ ) (Cao et al. 2014; Jiao et al. 2015; Zhang et al. 2011).
However, there was no detailed research on the in vitro and vivo characteristic of NZ2114 against S. suis-the pathogen of zoonosis got great public attentions in recent years. In this work, NZ2114 had the best activity against S. suis (MIC 0.03-0.06 $\mu \mathrm{M}$ ) (Table 1). In addition, it could 

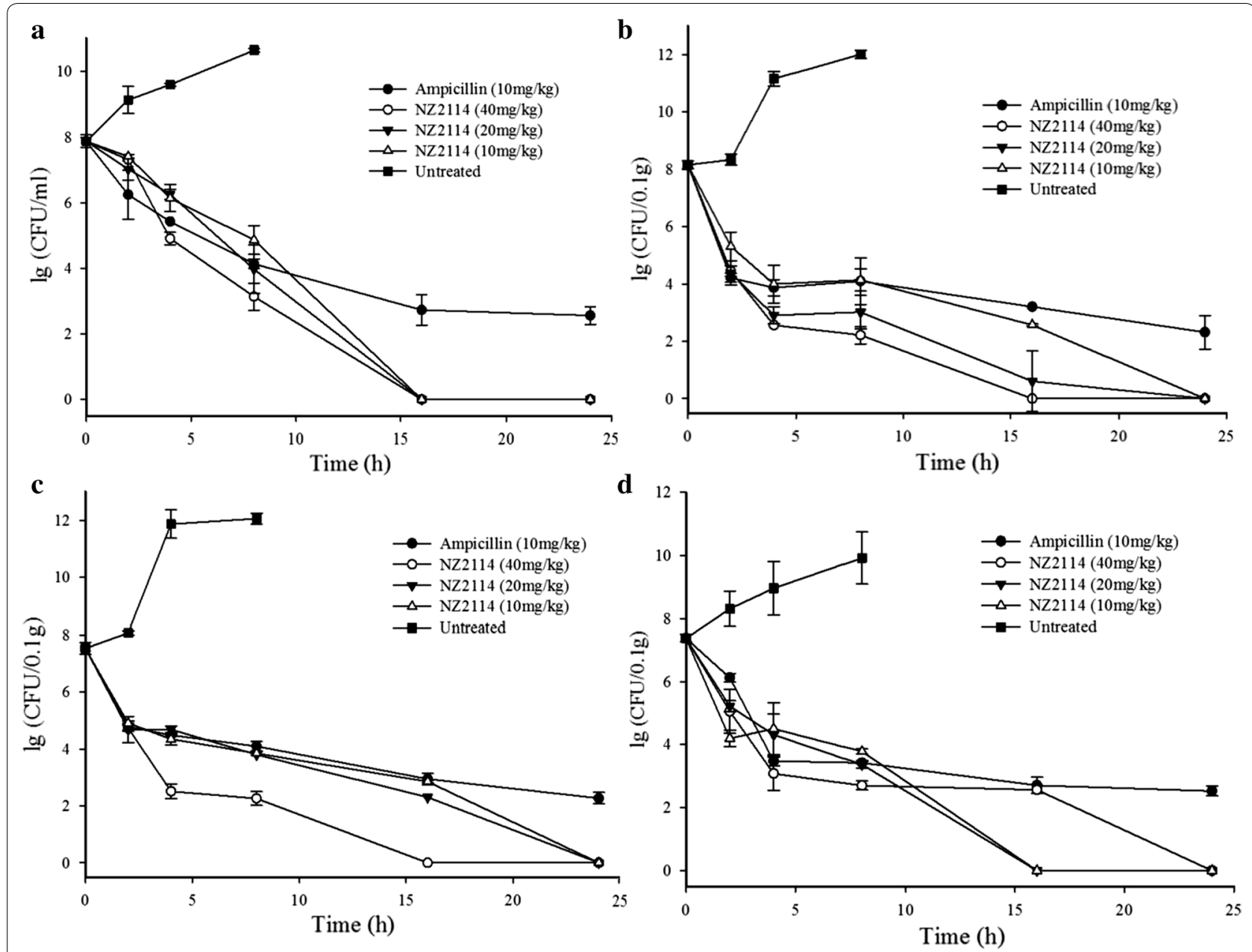

Fig. 4 Effects of NZ2114 on bacterial loads of S. suis in various organs. ICR female mice was inoculated with $1 \times 10^{8}$ CFU S. suis CVCC606 and various concentration (10,20, and $40 \mathrm{mg} / \mathrm{kg}$ ) of NZ2114 was injected after 1 and $8 \mathrm{~h}$ post-infection. The bacterial loads in blood (a), lung (b), spleen (c), and liver (d) were detected in 0, 2, 4, 8, and 16 h post-treatment. Every six mice were divided into one group and as duplicate, bars represent the standard error of the mean

kill 99\% pathogens within $4 \mathrm{~h}$ at 2 and $4 \times$ MICs $(0.06-$ $0.12 \mu \mathrm{M})$, having no bacterial regrowth after $4 \mathrm{~h}$ of inoculate (Fig. 1a). The MP1106 also significantly inhibited the growth of pathogen but was in high concentration $(0.24$ and $0.48 \mu \mathrm{M}$ for 4 and $8 \times \mathrm{MICs}$ ), there was no obvious bacterial regrowth only in the 8 and $16 \times$ MICs (Jiao et al. 2015). The more excellent anti-S. suis characteristic makes it as a potential antimicrobial drug for S. suis infection treatment.

The hemolysis was often evaluated for candidate AMPs as a new agent through intravenous injection (Park et al. 2006; Tian et al. 2009). NZ2114 and plectasin have been proven to have no hemolysis to human erythrocytes (less than $0.1 \%$ in $128 \mu \mathrm{g} / \mathrm{ml}$ ) and no toxicity to A549 cells, normal human bronchial epithelial cells, or lung fibroblasts in $50 \mu \mathrm{g} / \mathrm{ml}$ (Hara et al. 2008; Mygind et al. 2005;
Zhang et al. 2014). As expected, NZ2114 also showed a very low hemolytic activity $(<0.3 \%)$ against mouse erythrocytes even in the high concentration of $256 \mu \mathrm{g} /$ $\mathrm{ml}$ (Fig. 1b). The low toxicity to both model animal and human erythrocytes make it convenient for intravenous injection for further research and clinical use.

The plectasin and NZ2114 had potent activity in different animal infection models. The in vivo efficacy of plectasin $(10 \mathrm{mg} / \mathrm{kg})$ was comparable to vancomycin $(70 \mathrm{mg} /$ $\mathrm{kg})$ in the peritoneal model and to penicillin $(30 \mathrm{mg} / \mathrm{kg})$ in pneumonia model caused by S. pneumoniae (Mygind et al. 2005). It was shown that NZ2114 (10, 40 and $160 \mathrm{mg} / \mathrm{kg}$ ) could effectively killed S. aureus and S. pneumoniae in neutropenic murine thigh infection model. The counts of pathogen decreased over 99\% within $5 \mathrm{~h}$. There was regrowth with $10 \mathrm{mg} / \mathrm{kg}$ NZ2114 in $S$. 

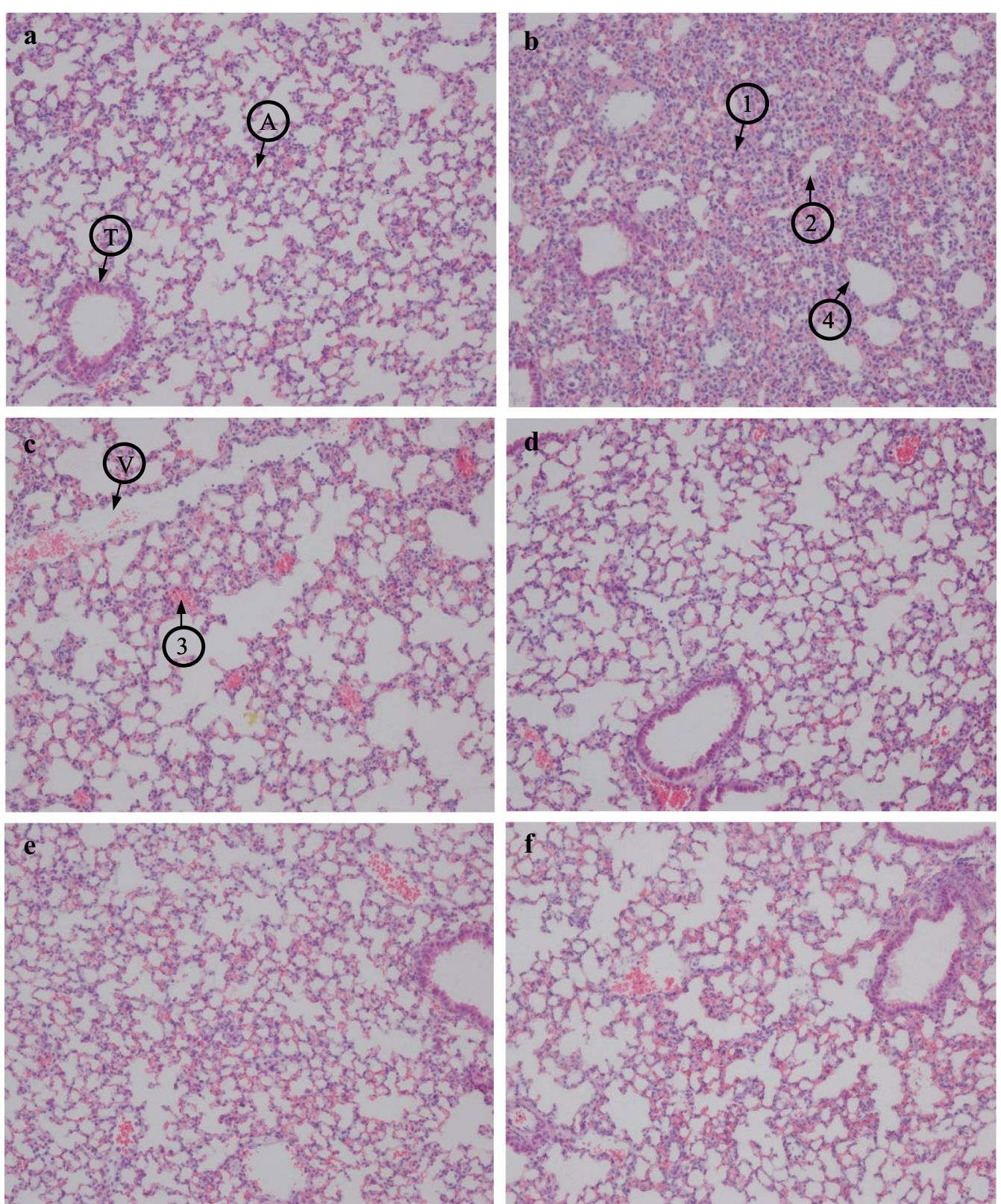

Fig. 5 Lung histopathology from different NZ2114 concentration experimental groups. ICR female mice were inoculated with $1 \times 10^{8}$ CFU S. suis CVCC606 and various concentration of NZ2114 (10,20, and $40 \mathrm{mg} / \mathrm{kg})$ was injected after 1 and $8 \mathrm{~h}$ post-infection. The mice were sacrificed after $24 \mathrm{~h}$ post-treatment and lung tissue was collected for histological evaluation. a Control group; b S. suis CVCC606 infection group; c S. suis CVCC606 + 10 mg/kg NZ2114; d S. suis CVCC606 + 20 mg/kg NZ2114; e S. suis CVCC606 + 40 mg/kg NZ2114; f S. suis CVCC606 + 20 mg/kg ampicillin. A alveoli, $T$ bronchioli terminals, $V$ vessel, 1 infiltration of inflammatory cells, 2 alveolar collapse, 3 alveolar hemorrhage, 4 bronchioli terminals epithelium damage

pneumoniae group and all dosage in S. aureus group after $5 \mathrm{~h}$ of therapy (Andes et al. 2009). Additionally, there was a significantly higher level of cerebrospinal fluid (CSF) penetration of NZ2114 through inflamed than through non inflamed meninges. Treatment with NZ2114 (40 and $20 \mathrm{mg} / \mathrm{kg}$ ), caused a significantly higher reduction in CSF bacterial concentrations than therapy with ceftriaxone $(125 \mathrm{mg} / \mathrm{kg})$ at 3,5 and $10 \mathrm{~h}$ (Ostergaard et al. 2009). In this work, NZ2114 showed strong activity to S. suis. The $0.2 \mathrm{mg} / \mathrm{kg}$ of it could save all infected mice (Fig. 3a) 

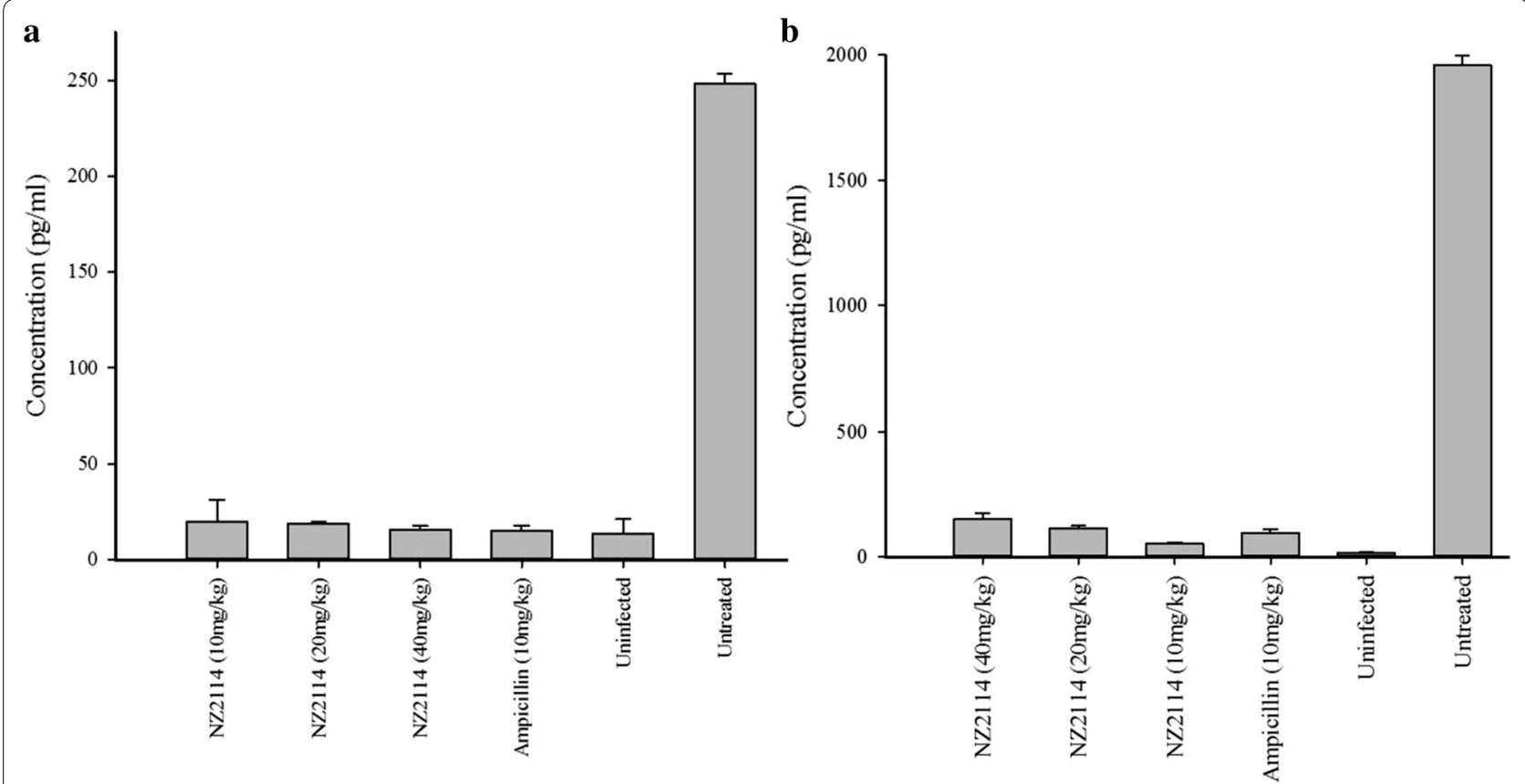

Fig. 6 Effects of NZ2114 on the pro-inflammatory cytokines of TNF-a and IL-6 in serum. ICR female mice were inoculated with $1 \times 10^{8}$ CFU S. suis CVCC606 and various concentration of NZ2114 (10,20, and $40 \mathrm{mg} / \mathrm{kg})$ was injected after $1 \mathrm{~h}$ post-infection. The mice were sacrificed after $24 \mathrm{~h}$ post-treatment and serum was collected for cytokines of TNF-a (a) and IL-6 (b) analysis. Three duplicate observations were made; bars represent the standard error of the mean

and there was no pathogen in blood $(5 \mathrm{mg} / \mathrm{kg})$ and lung $(10 \mathrm{mg} / \mathrm{kg})$ (Fig. 3b, c). S. suis loads of organs further revealed that there were no pathogen existed in blood, lung, liver and spleen after $24 \mathrm{~h}$ of treatment (twice injection, 1 and $8 \mathrm{~h}$ of postinfection) in all dosages (10, 20 and $40 \mathrm{mg} / \mathrm{kg}$ ) (Fig. 4). Other antimicrobial agents had the same effects but in high dosage. The $80 \mathrm{mg} / \mathrm{kg}$ (calculated at $25 \mathrm{~g}$ per rat) Ply30 (the bacteriophage lysin) protected $80 \%$ (8/10 mice) of mice from infection with S. suis. Seven days after lysin Ply30 treatment, bacterial loads were significantly decreased in all tested organs and blood compared with control group (Tang et al. 2015). It was shown that 8.6 and $28.02 \mathrm{mg} / \mathrm{kg}$ of cefquinome was required for 1-lg killing of S. suis ATCC 43765 with the initial inoculum of $10^{8}$ and $10^{6} \mathrm{CFU}$, respectively (Guo et al. 2016). The low injection dosage and high efficiency of NZ2114 in the mice model indicates that the drug resistance will be rare and it is suitable for the clinical treatment of $S$. suis infection.

Pulmonary injury could be the direct cause of S. suis -induced animal death (Lun et al. 2007). Lung inflammation is characterized by increased pulmonary inflammatory cell sequestration, which leads to the development of protein leakage in alveolar space, reduced lung compliance, and finally impaired lung function (Chu et al. 2010). It was shown that NZ2114 could reduce the lesions of lung tissues such as alveolar collapse and alveolar hemorrhage in a dose dependent manner, indicating that it is also conducive to the recovery of pulmonary injury.

TNF- $\alpha$ is the first endogenous cytokine released from monocytes and macrophages, which induces the inflammatory cascade and aggravates injuries (Malleo et al. 2007). Additionally, it leads to apoptosis by activating the caspases enzyme system in endothelial cells which compromises the integrity of the vascular barrier (Goldblum and Sun 1990). IL-6 is also a vital cytokine with strong influences on inflammatory responses and a crucial indicator (Strandberg et al. 2005). IL-10 has emerged as a key immunoregulator during infection. It can directly regulate innate and adaptive Th1 and Th 2 responses by limiting $\mathrm{T}$ cell activation and differentiation in the lymph nodes as well as suppressing proinflammatory responses in tissues, leading to impaired pathogen control and/or reduced immunopathology (Couper et al. 2008). In this work, NZ2114 clearly reduced the levels of TNF- $\alpha$, and IL-6 compared to the infection group (Fig. 6). These findings suggest that the protective effect of NZ2114 is partly attributed to inhibit the levels of pro-inflammatory cytokines. However, the level of anti-inflammatory IL-10 was ruleless (data not shown). Considering that IL-10 is pleiotropic functions, further studies are necessary to evaluate the immune state. 
In conclusion, NZ2114 showed strong antimicrobial activity against Gram-positive bacteria, especially to $S$. suis. It had very low hemolysis to mice RBCs in safe application concentrations. It was also found that NZ2114 had potent in vivo activity to $S$. suis. All mice were survival when the dosage was low to $0.2 \mathrm{mg} / \mathrm{kg}$ and no pathogens were detected in blood, lung, liver and spleen with dosage of 10,20 and $40 \mathrm{mg} / \mathrm{kg}$ after $24 \mathrm{~h}$ of treatment. Further, no pathological phenomenon in lung and low level of inflammatory cytokines in blood were detected. Above all, the in vitro and in vivo bactericidal profiles of NZ2114 indicating it is an ideal candidate for a new antimicrobial agent against $S$. suis infection.

\section{Abbreviations}

MIC: minimal inhibitory concentration; RBCs: red blood cells; PS: physiological saline; ICR: institute for cancer research; i.p.: intraperitoneally; i.v.: intravenously; AMP: anitimicrobial peptide; APD: antimicrobial peptide database; CSF: cerebrospinal fluid.

\section{Authors' contributions}

RYM, DT, and JHW conceived and designed the research. XMW and XW performed the in vitro experiment. JJ, NY, and $\mathrm{YH}$ performed the in vivo experiment and analyzed the data. RYM, XJF and JHW wrote the manuscript. All authors reviewed the manuscript. All authors read and approved the final manuscript.

\section{Author details}

${ }^{1}$ Key Laboratory of Feed Biotechnology, Ministry of Agriculture, Beijing 100081, People's Republic of China. ${ }^{2}$ Gene Engineering Laboratory, Feed Research Institute, Chinese Academy of Agricultural Sciences, 12 Zhongguancun Nandajie Street, Haidian District, Beijing 100081, People's Republic of China. ${ }^{3}$ Institute of Animal Nutrition, Northeast Agricultural University, Harbin 150030, People's Republic of China.

\section{Acknowledgements}

The authors would like to thank all the colleagues at Gene Engineering Laboratory, Feed Research Institute, Chinese Academy of Agricultural Sciences for their technical assistance throughout this study.

\section{Competing interests}

The authors declare that they have no competing interests.

\section{Availability of data and materials}

All datasets on which the conclusions of the manuscript were presented in the main paper.

\section{Ethical approval}

The animal protocol for this study was approved by the Animal Care and Use Committee of the Feed Research Institute, Chinese Academy of Agricultural Sciences (Beijing, China), and all mice involved were cared for in accordance with the institutional guidelines established by the Ministry of Science and Technology of the People's Republic of China. This article does not contain any studies with human participants by any of the authors.

\section{Funding}

This study was supported by the National Natural Science Foundation of China (Nos. 31372346, 31302004, 31572444, and 315724451), the Special Fund for Agro-scientific Research in the Public Interest in China (No. 201403047), and the AMP Direction of National Innovation Program of Agric Sci \& Technol in CAAS (CAAS-ASTIP-2013-FRI-02).

Received: 27 January 2017 Accepted: 14 February 2017

Published online: 20 February 2017

\section{References}

Andes D, Craig W, Nielsen LA, Kristensen HH (2009) In vivo pharmacodynamic characterization of a novel plectasin antibiotic, NZ2114, in a murine infection model. Antimicrob Agents Chemother 53:3003-3009

Breidenstein EBM, Courvalin P, Meziane-Cherif D (2015) Antimicrobial activity of plectasin NZ2114 in combination with cell wall targeting antibiotics against vana-type Enterococcus faecalis. Microb Drug Resist 21:373-379

Brinch KS, Tulkens PM, Van Bambeke F, Frimodt-Moller N, Hoiby N, Kristensen $\mathrm{HH}$ (2010) Intracellular activity of the peptide antibiotic NZ2114: studies with Staphylococcus aureus and human THP-1 monocytes, and comparison with daptomycin and vancomycin. J Antimicrob Chemoth 65:1720-1724

Cao X, Zhang Y, Mao R, Teng D, Wang X, Wang J (2014) Design and recombination expression of a novel plectasin-derived peptide MP1106 and its properties against Staphylococcus aureus. Appl Microbiol Biotechnol 99:2649-2662

Cho J, Lee DG (2011) The characteristic region of arenicin-1 involved with a bacterial membrane targeting mechanism. Biochem Bioph Res Co 405:422-427

Chu P-Y, Chien S-P, Hsu D-Z, Liu M-Y (2010) Protective effect of sesamol on the pulmonary inflammatory response and lung injury in endotoxemic rats. Food Chem Toxicol 48:1821-1826

Clifton-Hadley FA, Enright MR (1984) Factors affecting the survival of Streptococcus suis type 2. Vet Rec 114:584-586

Costa ATR, Lobato FCF, Abreu VLV, Assis RA, Reis R, Uzal FA (2005) Serotyping and evaluation of the virulence in mice of Streptococcus suis strains isolated from diseased pigs. Rev Inst Med Trop Sao Paulo 47:113-115

Couper KN, Blount DG, Riley EM (2008) IL-10: the master regulator of immunity to infection. J Immunol 180:5771-5777

Eckert R (2011) Road to clinical efficacy challenges and novel strategies for antimicrobial peptide development. Future Microbiol 6:635-651

Goldblum SE, Sun WL (1990) Tumor necrosis factor-alpha augments pulmonary arterial transendothelial albumin flux in vitro. Am J Physiol Lung Cell Mol Physiol 258:L57-L67

Guo C, Liao X, Wang M, Wang F, Yan C, Xiao X, Sun J, Liu Y (2016) In vivo pharmacodynamics of cefquinome in a neutropenic mouse thigh model of Streptococcus suis serotype 2 at varied initial inoculum sizes. Antimicrob Agents Chemother 60:1114-1120

Haesebrouck F, Pasmans F, Chiers K, Maes D, Ducatelle R, Decostere A (2004) Efficacy of vaccines against bacterial diseases in swine: what can we expect? Vet Microbiol 100:255-268

Halaby T, Hoitsma E, Hupperts R, Spanjaard L, Luirink M, Jacobs J (2000) Streptococcus suis meningitis, a poacher's risk. Eur J Clin Microbiol Infect Dis 19:943-945

Hara S, Mukae H, Sakamoto N, Ishimoto H, Amenomori M, Fujita H, Ishimatsu Y, Yanagihara K, Kohno S (2008) Plectasin has antibacterial activity and no affect on cell viability or IL-8 production. Biochem Biophys Res Commun 374:709-713

Higgins R, Gottschalk M (2000) Distribution of Streptococcus suis capsular types in 1999. Can Vet J 41:414

Hoa NT, Chieu TTB, Nghia HDT, Mai NTH, Anh PH, Wolbers M, Baker S, Campbel JI, Chau NV, Hien TT, Farrar J, Schultsz C (2011) The antimicrobial resistance patterns and associated determinants in Streptococcus suis isolated from humans in southern Vietnam, 1997-2008. BMC Infect Dis 11:6

Jiao J, Mao R, Wang X, Zhang Y, Teng D, Feng X, Wang J (2015) GAP-initiated constitutive expression of a novel plectasin-derived peptide MP1106 by Pichia pastoris and its activity against Streptococcus suis. Process Biochem 50:253-261

Lun ZR, Wang QP, Chen XG, Li AX, Zhu XQ (2007) Streptococcus suis: an emerging zoonotic pathogen. Lancet Infect Dis 7:201-209

Mai NT, Hoa NT, Nga TV, Linh le D, Chau TT, Sinh DX, Phu NH, Chuong LV, Diep TS, Campbell J, Nghia HD, Minh TN, Chau NV, de Jong MD, Chinh NT, Hien TT, Farrar J, Schultsz C (2008) Streptococcus suis meningitis in adults in Vietnam. Clin Infect Dis 46:659-667

Malleo G, Mazzon E, Siriwardena AK, Cuzzocrea S (2007) TNF-alpha as a therapeutic target in acute pancreatitis - lessons from experimental models. Sci World J 7:431-448

Mygind PH, Fischer RL, Schnorr KM, Hansen MT, Sönksen CP, Ludvigsen S, Raventós D, Buskov S, Christensen B, De Maria L, Taboureau O, Yaver D, Elvig-Jørgensen SG, Sørensen MV, Christensen BE, Kjærulff S, FrimodtMoller N, Lehrer RI, Zasloff M, Kristensen H-H (2005) Plectasin is a peptide 
antibiotic with therapeutic potential from a saprophytic fungus. Nature 437:975-980

Normile D (2005) Infectious diseases - WHO probes deadliness of China's pigborne disease. Science 309:1308-1309

Ostergaard C, Sandvang D, Frimodt-Moller N, Kristensen HH (2009) High Cerebrospinal fluid (CSF) penetration and potent bactericidal activity in CSF of NZ2114, a novel plectasin variant, during experimental pneumococcal meningitis. Antimicrob Agents Chemother 53:1581-1585

Park Y, Park SN, Park S-C, Shin SO, Kim J-Y, Kang S-J, Kim M-H, Jeong C-Y, Hahm K-S (2006) Synergism of Leu-Lys rich antimicrobial peptides and chloramphenicol against bacterial cells. BBA Proteins Proteom 1764:24-32

Schneider T, Kruse T, Wimmer R, Wiedemann I, Sass V, Pag U, Jansen A, Nielsen AK, Mygind PH, Raventos DS, Neve S, Ravn B, Bonvin AMJJ, De Maria L, Andersen AS, Gammelgaard LK, Sahl HG, Kristensen HH (2010) Plectasin, a fungal defensin, targets the bacterial cell wall precursor lipid II. Science 328:1168-1172

Strandberg Y, Gray C, Vuocolo T, Donaldson L, Broadway M, Tellam R (2005) Lipopolysaccharide and lipoteichoic acid induce different innate immune responses in bovine mammary epithelial cells. Cytokine 31:72-86

Strangmann E, Froleke H, Kohse KP (2002) Septic shock caused by Streptococcus suis: case report and investigation of a risk group. Int J Hyg Envir Heal 205:385-392

Suankratay C, Intalapaporn P, Nunthapisud P, Arunyingmongkol K, Wilde H (2004) Streptococcus suis meningitis in Thailand. Southeast Asian J Trop Med Public Health 35:868-876

Tang F, Li D, Wang H, Ma Z, Lu C, Dai J, Drake HL (2015) Prophage lysin Ply30 protects mice from Streptococcus suis and Streptococcus equi subsp. zooepidemicus infections. Appl Environ Microb 81:7377-7384

Tian ZG, Dong TT, Teng D, Yang YL, Wang JH (2009) Design and characterization of novel hybrid peptides from LFB15 (W4, 10), HP (2-20), and cecropin A based on structure parameters by computer-aided method. Appl Microbiol Biotechnol 82:1097-1103

Varela NP, Gadbois P, Thibault C, Gottschalk M, Dick P, Wilson J (2013) Antimicrobial resistance and prudent drug use for Streptococcus suis. Anim Health Res Rev 14:68-77

Vela Al, Morena MA, Cebolla JA, Gonzalez S, Latre MV, Dominguez L, Fernandez-Garayzabal JF (2005) Antimicrobial susceptibility of clinical strains of Streptococcus suis isolated from pigs in Spain. Vet Microbiol 105:143-147

Wertheim HFL, Nghia HDT, Taylor W, Schultsz C (2009) Streptococcus suis: an emerging human pathogen. Clin Infect Dis 48:617-625

Xiong YQ, Hady WA, Deslandes A, Rey A, Fraisse L, Kristensen H-H, Yeaman MR, Bayer AS (2011) Efficacy of NZ2114, a novel plectasin-derived cationic antimicrobial peptide antibiotic, in experimental endocarditis due to methicillin-resistant Staphylococcus aureus. Antimicrob Agents Chemother 55:5325-5330

Yeung ATY, Gellatly SL, Hancock REW (2011) Multifunctional cationic host defence peptides and their clinical applications. Cell Mol Life Sci 68:2161-2176

Zasloff M (2002) Antimicrobial peptides of multicellular organisms. Nature 415:389-395

Zhang J, Yang Y, Teng D, Tian Z, Wang S, Wang J (2011) Expression of plectasin in Pichia pastoris and its characterization as a new antimicrobial peptide against Staphyloccocus and Streptococcus. Protein Expr Purif 78:189-196

Zhang Y, Teng D, Mao R, Wang X, Xi D, Hu X, Wang J (2014) High expression of a plectasin-derived peptide NZ2114 in Pichia pastoris and its pharmacodynamics, postantibiotic and synergy against Staphylococcus aureus. Appl Microbiol Biotechnol 98:681-694

\section{Submit your manuscript to a SpringerOpen ${ }^{\circ}$ journal and benefit from:}

- Convenient online submission

- Rigorous peer review

- Immediate publication on acceptance

- Open access: articles freely available online

- High visibility within the field

- Retaining the copyright to your article

Submit your next manuscript at $\boldsymbol{\nabla}$ springeropen.com 